Article

\title{
How Avoiding the Religion-Politics Divide Plays out in Sikh Politics
}

\author{
Pashaura Singh $\mathbb{D}$ \\ Department of Religious Studies, University of California, Riverside, CA 92521, USA; psingh@ucr.edu
}

Received: 15 March 2019; Accepted: 24 April 2019; Published: 28 April 2019

\begin{abstract}
This article looks at the intersection of religion and politics in the evolution of the Sikh tradition in the pre-colonial, colonial and post-colonial periods in the Indian subcontinent. The Sikh notion of sovereignty is at the heart of the intersection of religious and secular domains, and this relationship is examined empirically and theoretically. In particular, the conception of mīrī-pīrī is presented as a possible explanation for understanding the 'new developments' in contemporary Sikh politics in India.
\end{abstract}

Keywords: Akal Takhat; British Raj; halemī rāj; Khalsa; mīrī-pīrīi religion and politics; secularism; SGPC; Akali Dal; Punjab

\section{Introduction}

The purpose of this essay is to look at the changing dynamics of the intersection of religion and politics at various historical junctures in the evolution of the Sikh tradition, thereby understanding the more recent developments in Sikh politics in the Punjab. Notably, the distinction between the public and private spheres did not exist in the early Sikh tradition prior to the colonial rule of the early 19th century. The Sikh Gurus mediated the two spaces as one. For them and for societies of that time in India, this division did not exist. This is the same division as between religion and politics, or between church and state. In recent studies, "religion" is not considered simply a belief system or a purely interior impulse secreted away in the human soul and limited to the private sphere, or an institutional force separable from other non-religious or secular forces in the public domain. Rather, religion in today's world is understood as a living, vibrant, social formation. It is broadly understood to encompass not only institutional forms of religion but also ethical, ritual or social issues that form a part of religious milieu. Similarly, "politics" is broadly conceived to encompass not only government structures or political parties but also the social movements that tend to influence, sooner or later, the values that shape government policies. The idea of the 'public sphere' is a European invention, which divides it from private space at the time, when church and state separated after the 15th century in Europe. The most widely-known theory of the public is Habermas's concept of the "public sphere" (Habermas 1989). In its original formulation, the "public sphere" was intended to describe a unique structural transformation in European society. In particular, late 17th-century Europe witnessed the emergence of a public domain, in which public opinion was crafted through the process of rational debate. This "bourgeois public sphere" coincided temporarily with the "rise of political liberalism and early capitalist social orders, forming a necessary foundation for constitutional democracy as we understand it today" (Fisher 2017, p. 21).

In her recent article, Amanda Lucia has skillfully shown how during the independence movement, M. K. Gandhi modeled an embodied confluence between politics, social responsibility, and religion. In the post-independence period, India has reverted to indigenous models of close collaboration between the political and religious fields. In fact, contemporary Hindu religious leaders have become prominent actors in the public sphere, rejecting the western ideal that the privatization of religion is 
an essential component of modernity. Instead, their asceticism blends seamlessly with routine media appearances and their abilities to hold public office, to lead social service and humanitarian campaigns, to become global ambassadors for Hinduism. They have become spokespersons of a new vibrant global Hinduism, including those who tired of Gandhi's tolerant ecumenism and sought to construct India as an exclusively Hindu nation. Modern-day Hindu leaders have become public officials with exceptional influence in India's governance, to the extent that Hindu dominance and self-proclaimed supremacy threatens the secular character of India's social democracy and its religiously diverse citizenry (Lucia 2019).

In the present context, the Sikh refusal to buy into the dichotomy between religion and politics is making a difference in contemporary Indian and Punjab politics. In particular, the Sikh doctrine of mìri-piri (Secular-Religious) affirms that religion and politics are bound together, thereby allowing religious issues to be defended in the political arena and political activity to be conducted in accordance with the religious values of truth and social justice. We can comprehend this intersection between religion and politics in contemporary Punjab only if we try to understand briefly the historical development of early Sikh tradition by means of the Sikh Gurus' attitude to minority formations in the face of powerful politics of Mughal Empire and in the face of hegemonic Brahminical traditions. For this purpose, we will address the following questions: How did Guru Nanak (1469-1539) and his successors resist what some scholars and interpreters understand as the brutal state structures of their times? How have these attitudes of resistance changed in the current period? Is there also any continuity in modern times? We will address these issues by examining canonical Sikh sources.

To understand the intersection of religion and politics at different historical junctures, let us begin with the notion of sovereignty from the Sikh perspective. The term 'sovereignty' refers not only to the ability but also the right to freely express one's life-world, with the "power to authorize" one's own speech. In his dialogue with the followers of the Nath tradition, Guru Nanak was asked: "Who is your Guru, by whom you have been authorized?" The Guru responded: "The divine Word (shabad) is my Guru, I am a disciple of the state of consciousness (surti) that arises from its ever resounding vibration" (Guru Granth Sahib [GGS], p. 943). Thus, the state of consciousness, whose essential mark is the equipoise between ego and ego-loss, became the foundation for Guru Nanak's power of self-authorization. Guru Nanak always invoked Akāl Purakh ("Eternal One," God) as Sachā Pātishāh, the "True Sovereign" (GGS, p. 463), whose hukam ("divine will, order or command") supersedes all temporal authority. He bequeathed the concept of sovereignty to one and all by asserting that if God is the 'True Sovereign' in the spiritual and temporal realm, then a human being as a creation of God partakes of the sovereignty of the Divine. Jasbir Singh Ahluwalia maintains that the divinity of God is the source of the sovereignty of the human person: to be fearless is to be free, and to be free is to be sovereign. Providing the philosophical basis for the sovereignty of a human being, therefore, Guru Nanak predicated God as "Fearless" and "Devoid of Enmity" in the Mūl Mantar (Ahluwalia 1983, p. 148). The Punjabi word for 'sovereignty' is patishāh $\bar{\imath}$ that is frequently employed by Guru Nanak and his successors in the Sikh scripture (GGS, pp. 5, 48, 144, 590, 749, and 1073). For Guru Nanak, this sovereign consciousness comes only when one overcomes one's self-centeredness or ego (haumai) through the discipline of meditation on the divine Name (näm simran): "One who is blessed with the gift of singing the praises of the Lord, O Nanak, is the king of all kings" (GGS, p. 5). Thus, sovereign consciousness overflows with the sense of fearlessness and compassionate love for everyone.

Guru Nanak himself was not content to leave the ethical principles that he expounded in his life as merely theoretical constructs, but instead sought to institutionalize them during the last two decades of his life at Kartarpur. He referred to the earth (dhart $\bar{\imath})$ as the place to practice righteousness (GGS 7) and his own village was conceived as a place of justice where the divine will was carried out. The congregation assembled at the Guru's house at Kartarpur symbolized the establishment of divine sovereignty on earth. There, Guru Nanak lived as the 'spiritual guide' of a newly emerging religious community. His attractive personality and teachings won him many disciples, who received his message of liberation through religious hymns of unique genius and notable beauty. He was the central 
authority for the early Sikh community and the definer of tradition for his age. He placed explicit emphasis on the ideal of moderate living in the world in which spiritual development and activist social engagement through selfless 'service' (sevā) went hand in hand.

In Guru Nanak's view, the key discipline of meditation on the divine Name (nām simaran) was meant to liberate oneself from the shackles of ego or self-centeredness (haumai). The word simaran is derived from the Sanskrit root marana, meaning "to die" or "pass away," suggesting that this process is a form of remembrance that automatically lets go of one's self-centeredness. It is remembrance of one's own mortality, of the ego's death, remembering which one awakens to the reality of the divine Name. It is the condition of experience of finitude in the first place, leading to an awareness of the eternally sounding vibrations of the divine Name and making it a sacrificial practice for transforming memory by eliminating one's ego consciousness. It provides the means for an individual to actively participate and make changes in the world. It is as inherently spiritual as it is secular. For Guru Nanak and his successors, there was no contradiction between mystical experience and the life of a householder, soldier, or political leader (Mandair 2013, p. 155). Although Guru Nanak viewed the apprehension of the divine Name (nām) in terms of interior devotion, his emphasis on the extension of the knowledge gained in the process must be acknowledged. This extension of an interiorly gained understanding of the divine Name is predicated upon social responsibility and as such should be seen as movement away from the subjective speculation of the medieval poet-saints of North India.

Here, it is instructive to note that some scholars have pointed towards the 'hegemony' of the Khalsa-centric interpretation of the Sikh tradition (Axel 2004; Jakobsh 2015). Accordingly, the triumphalist narrative of the Khalsa began to inspire the imaginations of certain Sikhs in the 19th century, and later motivated the British to incorporate Sikhs into their notorious colonial endeavor, which in turn reified the interpretation that became dominant in scholarly circles. However, another way to look at these scholars' writings is that their observations derive from a skewed understanding of the institution of the Khalsa as simply the 'military-wing' of the Sikh Panth ('community') that originated in the face of Mughal persecution. This particular understanding is based on the 'early pacifism versus later militancy' discourse that has dominated in popular writings on Sikhism. This discourse draws attention to the apparent contradiction between the interior devotion of the early Nanak-panth ('followers of Guru Nanak's path') and the militant character of the Khalsa tradition. For instance, Khushwant Singh's history of the Sikhs contains a chapter entitled, 'From the Pacifist Sikh to the Militant Khalsa' (Singh 1999, pp. 76-98). No serious scholar today ascribes to Singh's pacifism versus militancy argument. Following the Orientalist paradigm, such works ignore contextual depth and misrepresent the process of evolution by focusing too much on the apparent 'contradiction' between 'religion' and 'politics' in the Sikh tradition (Singh 2012, p. 201). The present study offers a counter-perspective to the framework of "early pacifism verses later militancy" discourse. It challenges the reductionist approach that defines the Sikh culture simply as a religion of interior devotion limited essentially to the private sphere without taking into account its relevance in political, economic and social arenas of public sphere.

\section{Historical Context of Early Sikh Formations}

Guru Nanak kindled the fire of autonomy and courage in those who claimed to be his disciples (sikh, "learners"). He inspired them to stand up against any kind of injustice and tyranny. For them, he set an example to raise one's voice at the right moment from the standpoint of truth and social justice: "Nanak speaks the Word of Truth; he proclaims the Truth at the most appropriate moment of time" (GGS, p. 723). This proclamation was made in the historical context of Babur's invasion of India when Guru Nanak was standing in "the city of corpses" (ibid.). He frequently condemned the corrupt and violent state structures of his times. During his invasion to secure northern India in the 1520s, the first Mughal emperor, Babur (1483-1530), achieved his final victory over Ibrahim Lodhi in 1526 in the field of Panipat. Most instructively, Guru Nanak commented upon the violence inflicted on innocent people in his four hymns, collectively known as Bābar-vāṇ̄ ("Utterances concerning Babur”, 
GGS, pp. 360, 417-18 and 722-23). In fact, these hymns provide an eyewitness account of Babur's invasion of India and throw considerable light on the devastation caused by his army. He was pained to see the suffering of the innocent who had little to do with politics and war: "You spared Khurasan but yet spread fear in Hindustan. Creator, you did this, but to avoid the blame you sent the Mughal as the messenger of death. Receiving such chastisement, the people cry out in agony and yet no anguish touches you. Creator, you belong to all. If the mighty destroy only one another, one is not grieved" (GGS, p. 360). The principal theme in his $\bar{A} s \bar{a}$ hymn is related to the question of why the weak and innocent should suffer unmerited torment at the hands of the strong and in this respect this hymn has obvious affinities with the Book of Job in the Hebrew Bible. God is called into account, just as Job summons him. Guru Nanak makes it quite explicit that it was the Creator who sent Babur as the messenger of death to destroy the Lodhi Sultanate. He underscored the point that if any mighty person attacks "the weak and unarmed" person, then it is a violation of an ethical norm of warfare (Singh 1989, p. 116).

Guru Nanak's response to war and suffering is not limited to his personal anguish. A careful examination of his works reveals a powerful condemnation of both the invaders and the rulers. Guru Nanak describes the Lodhis as "wretched dogs" for their moral failure to protect their sovereignty and the innocent people. They had acted in a manner contrary to the divine intention and were responsible for the ultimate overthrow of their dynasty. In the Tilang hymn, on the other hand, Guru Nanak refers to Babur's army as the "marriage-party of sin," and thus charges them for their moral failure to forcibly demand a "dowry" from the suffering people (GGS, p. 722). Elsewhere, Guru Nanak holds heedlessness of Akal Purakh on the part of the general public responsible for bringing about this retribution. In the case of the rape of women, for instance, the Guru makes the following comment: "The wealth and sensual beauty which intoxicated them became their enemies. The messengers of Death, under orders to persecute, strip them of their honor and carry them off" (GGS, p. 417). Here, Guru Nanak is not blaming women's own behavior for being raped but rather describing the obduracy of human nature. All the violence in war and rape was caused by the senseless pursuit of worldly pleasures and heedlessness of Akal Purakh. Some other verses represent a terrible portrait of women being raped by soldiers who did not bother to discriminate between Hindus and Muslims who were in their path: "Some lost their five times of prayer, some the time of puja" (GGS, p. 417). Thus, Guru Nanak was deeply anguished over the horrible situation of women. He employed the Punjabi phrase "stripping of one's honor" to describe the rape of women by the Mughal army. In fact, rape is regarded as a violation of women's honor in Punjabi culture. For all his sympathy with the suffering people, Guru Nanak was cognizant of the situation of poor women and their agony reminded him of a religious truth that unrighteousness would be punished according to divine justice.

Guru Nanak was fully aware of the relationship between the two existing domains of temporal and spiritual sovereignties (mîri $\bar{\imath}-p \bar{\imath} r \bar{r})$ in contemporary India. He employed the key words pir (saint) and $\mathrm{mir}$ (sovereign), representing religious and secular powers in early 16th century. In his $\bar{A} s \bar{a}$ hymn, he claimed that the religious leaders miserably failed to halt the invader with their miraculous tricks, by falsely claiming that the Mughals will be blinded when they arrive (GGS, pp. 417-19). Riding on their fast-running horses, the Mughals fired their guns on the army of Pathans on their elephants. Guru Nanak thus admitted the enormity of violence caused by Babur's army as part of Mughal invasions of India, but he rendered it small from the perspective of a larger metaphysic of divine Order (hukam). Guru Nanak fully realized that unchecked political power could easily crush the religious authority of saintly people. He sowed the seeds of mìri-piri tradition in his bold resistance against the power structures of his times. One can raise the issue of the Bābar-vān $\bar{\imath}$ being the exception in the context of the overall emphasis of Guru Nanak's teachings of interior devotion. This is simply not the case. Guru Nanak's critique of political structures of his times may be seen in his other works, particularly in his Vār Mājjh (GGS, p. 145), Vār Āsā (GGS, pp. 468-69) and Vār Malār (GGS, p. 1287-88). 
The most poignant analysis of the complexity of state violence is given in Guru Nanak's Malār hymn. Here, the Guru employs the metaphors of deer (haran), hawks (bāj) and state officials (siqdār) who act as trained agents-provocateurs to push a community in a particular direction, especially on the path of self-destruction. For instance, if a hunter wants to catch the herd of deer's in the forest, he will pick up a 'baby deer'. He will then feed him to raise him in a particular way so that the deer becomes fully dependent upon the hunter. After the deer is fully trained, the hunter will let him loose in the forest where he becomes the leader of other deers. Eventually, the trained deer will bring the herd of deers into the trap of the hunter. Similarly, a trained hawk will lead other hawks into the snare of the hunter. The original hymn reads as follows:

\section{Mahalā 1 (Guru Nanak).}

Deer, hawks, and government officials are known to be trained and clever. When the trap is set, they trap their own kind; hereafter, they will find no place of rest. He alone is learned and wise, and he alone is a visionary scholar (pandit binnā) who practices the divine Name. First, the tree puts down its roots, and then it spreads out its shade above [to protect people from sun]. The kings become tigers—[beasts of prey]—and their officials become greedy dogs; they go out and awaken the sleeping people to terrorize them. The public servants inflict wounds with their nails: O dogs! Lick the blood and marrow of the poor. Behold, where creatures will be judged [according to their deeds]; there, the noses of these tyrants will be chopped off [in disgrace] and they will be branded as untrustworthy [in the divine court]. (GGS, p. 1288)

Most of the time, Sikh scholars have a tendency to pick up few lines of this hymn to show Guru Nanak's powerful critique of the rulers and the invaders alike that is partially true. There is a need to maintain the structural unity of this hymn in exegesis so that we can appreciate its true import. In addition to the condemnation of despotic rulers, Guru Nanak offers a severe critique of the agency of various human actors from within the community who are actually responsible for much of its agony. In the Sikh scripture, for instance, a 'deer' appears as the symbol of 'illusion' without the knowledge that the real 'musk' (kastūuri) lies in his own body but looks outside in bewilderment. A 'hawkish' person employs his 'surrogate power' to bring oppression to his own people. Similarly, agents-provocateurs act as 'extended arms' of state machinery to carry out its evil designs.

In the Malār hymn, Guru Nanak presents his own take on violence as politically motivated. He strongly condemns the rulers and the agents of state structures for being ultimately responsible for mass killings. The three categories of people described in this hymn as deer, hawks and agents-provocateurs are actually responsible for creating a situation for state repression. The fourth category consists of 'visionary intellectuals' (pandit bin $\bar{a}$ ) who maintain their integrity in all circumstances without shifting their positions. By practicing the discipline of the divine Name (nām-simran), they protect the interests of their community much in the same way as a shady tree protects people during a hot summer. Here, the metaphor of a 'tree' is significant because it is rooted, grounded, unwavering, and does not get distracted from the present moment. Therefore, the ideal persons in Guru Nanak's view are taught to persist similarly rooted, grounded, and unwavering in their meditation on the divine Name, whether they be sitting, walking, or amidst the bustle of everyday life. They live and die protecting the honor and dignity of their faith and community. In Guru Nanak's usage, the Punjabi term pati essentially refers to the core of a person, encompassing honor, self-respect and social standing. The Guru proclaims: "He alone truly lives in whose heart dwells the Lord. O Nanak, no one else is truly alive. If one lives in ignominy by losing one's self-respect (pati), all that one eats [for survival] is illegitimate" (GGS, p. 142).

Most interestingly, an entry in a copy of the Goindval volumes (pothiss), complied in the late 16th century, describes Guru Nanak as "Emperor Bedi protective of matters religious and temporal" (Mann 1996, p. 97). This title illuminates the unique Theo-political status of the Guru in the 16th-century Sikh community. Before he passed away in 1539, Guru Nanak appointed his disciple Laihṇā to be his 
successor, by renaming him as Angad ("My own limb"). The contemporary bards, Sattā and Balvaṇd, have employed royal terminology to describe Guru Nanak's establishment of a divine 'kingdom' $(r \overline{a j})$ at Kartarpur on the solid foundation of Truth, embellishing it with royal metaphors such as the 'creation of a castle', 'striking of a coin', and calling the ceremony of the Guru's succession the 'royal coronation'. Having installed a royal canopy over Laihnā's head, the Guru applied the ceremonial mark to his forehead and bestowed on him the patrimony of the sword of spiritual knowledge, power and heroism to provide effective leadership to the growing Sikh community. The most astonishing act of Guru Nanak in this ceremony of 'royal coronation' was to bow down to his disciple while he was still alive (GGS, p. 966). Guru Angad (1504-1552) chastised the Mughal Emperor Humayun, when he visited the Guru at Khadur following his defeat at the hands of Sher Shah Suri at the Battle of Khanua in 1540 CE. An early narrative in the Mahimā Prakāś Vārtak states that as Humayun was kept standing for about $46 \mathrm{~min}$ (due ghari $\bar{l}$ ) in the presence of the Guru, he lost his patience and attempted to lash out while the Guru was playing with children (Bajwa 2004, pp. 62-63). Guru Angad reminded the visitor: "O Mughal! Was this sword meant to be drawn against Sher Shah in the battlefield or against us now [by posing a hero to strike against the saintly people]?" (Bajwa 2004, p. 63). At the end of this verbal encounter, we find Guru Angad blessing the Mughal emperor, reassuring the now-humiliated Humayun that he will regain his lost throne in the near future (Fenech 2014, pp. 41-42). Once again, we hear the voice of Truth speaking to the power of a haughty emperor.

Further, there is contemporary evidence that a group of Brahmins living in Goindval complained against Guru Amar Das (1479-1574) to the Lahore administration (GGS, p. 306). The third Guru dispatched his son-in-law, Ram Das, to Lahore to meet with Emperor Akbar (r. 1556-1605) in order to answer grievances that Brahmins raised in the royal court. They raised objections against running a free community kitchen (langar) at Goindval, abandoning the traditional religious and social customs and ignoring distinctions of four castes. Ram Das's simple statement that all are equal in the eyes of God pleased Akbar, who dismissed the accusations of the appellants (Bajwa 2004, pp. 76-77). The formation of a minority Sikh community was thus facing these early struggles in the face of powerful politics of Mughal authorities and hegemonic Brahminical traditions. Under these circumstances, Guru Amar Das inspired his audience to remain steadfast by practicing the discipline of meditation on the divine Name (nām simaran) in conjunction with selfless service (sevā) to fellow beings. He contrasted the "true sovereignty" of the devotees of God with the "false sovereignty" of worldly rulers: "The Lord blesses his humble devotees with sovereignty (pātishāh $\bar{\imath})$ ), fashioning the true crown upon their heads. They are always at peace, and immaculately pure; they perform service for the True Guru. By contrast, we should not call those to be kings, who die in conflict, and then enter again the cycle of reincarnation" (GGS, p. 590).

Akbar became curious about the newly emerging Sikh community. His incidental visit to meet with the third Guru, Amar Das, at Goindval in 1571 was the beginning of cordial relationship between the Sikhs and the Mughals. By that time, the institution of the community kitchen (laingar) had become a permanent feature of the Sikh Panth. The Guru made the compulsory rule of commensality: "First sit in the status-free lines to eat the common meal, and then meet with the Guru in the congregation." This striking phrase has its origins in the narrative of Mahimā Prakāś Vārtak, in which Guru Amar Das proclaimed that Akbar "should partake in the sacred food prepared in the community kitchen before seeking the Guru's audience" (Bajwa 2004, p. 86). The fourth Guru, Ram Das (1534-1581), provides us with a contemporary reflection on this meeting: "Kings and emperors are all created by God; they all come and bow in reverence to God's humble servant" (GGS, p. 305). On this occasion, Akbar offered a grant of revenue-free land to the Guru. Upon his refusal to accept the gift in keeping with the Sikh tradition of self-reliance, it was given to the Guru's daughter Bibi Bhani, implying that the revenue-free land went to her husband, Guru Ram Das. In order to lessen the potential for rivalry from his sons, Guru Amar Das decided to establish a new settlement for his son-in-law and successor, Guru Ram Das. The fourth Guru laid the foundation of the new town in 1577, when he inaugurated the excavation of 
the large pool called Amritsar at the original site. The fifth Guru, Arjan (1563-1606), inherited this place from his father when he assumed the office of the Guru in 1581.

\subsection{Establishing a Divine Kingdom at Ramdaspur}

Religious communities around the world frequently critique the temporal authority of worldly rulers with the utopian idea of a divine kingdom where diverse groups of people live with peace and harmony. The reality of a divine kingdom became unmistakable in Guru Arjan's proclamation: “There is no other place like the beautiful and thickly populated Ramdaspur. The divine rule prevails in Ramdaspur due to the grace of the Guru. No tax (jizya $)$ is levied, nor any fine; there is no collector of taxes" (GGS, pp. 430, 817). The administration of the town was evidently in the hands of Guru Arjan. In a certain sense, Ramdaspur was an autonomous town in the context and framework of the Mughal rule of Emperor Akbar. Guru Arjan's claim that there was no collector of taxes at Ramdaspur points toward a reality that it came under the authority of the Guru, not under the Mughal state.

In a particularly striking composition, Guru Arjan claims to have established the rule of justice and humility (halemi $r \bar{a} j$ ) in the town of Ramdaspur: "The merciful Lord has now ordained a commandment that none shall be domineering over others. All shall abide in peace, prosperity and justice. Thus is established the rule of justice and humility on earth" (GGS, p. 74). This text clearly indicates that Guru Arjan enacted the divine rule in actual practice in providing comfortable living to the people at Ramdaspur. It is no wonder that the early Sikhs were preoccupied with the understanding of the spiritual roots of the principles of justice, dignity and fearlessness. In fact, the idea of the divine rule of justice and humility (halemī rāj) occurs in Guru Arjan's lengthy composition molded on the style of Guru Nanak's preceding composition of twenty-two verses in Sirī Rāgu. These two hymns are remarkably interconnected in terms of important themes. For instance, Guru Nanak makes the following assertion in the nineteenth verse: "O Sovereign! You are the ultimate authority over the kings and emperors. Nanak lives by contemplating your Name" (GGS, p. 72). As an ideal, divine rule transcends and judges human rule. Discourse about rule is always centered on power and privilege, and on the rights and duties of those who have it. It involves a process much more than a place, a way of life much more than a location on particular territory. Therefore, the main focus here is not on kings but on rulers, not on kingdom but on power, not on territory but on process. In this context, Guru Arjan's idea of divine rule was related to an ethical way of life based on the principles of truth, social justice and humility taught by Guru Nanak. This life style would create the spirit of fearlessness among the contemporary Sikhs, particularly the residents of Ramdaspur, who would feel that they were directly under the protection of God, the King of all kings. No worldly power could disturb their peace of mind.

One must not underestimate the powerful appeal of Guru Arjan's verses in their socially subversive function. The common people, particularly the peasantry of the Punjab, could easily interpret their message in political terms. For the Sikhs, Guru Arjan was indeed a "true king" (sachā patishāh) in contrast to the false rulers of the world. His personal authority and appeal rested on his charismatic ability to embody Divine Power. His reign was marked by a number of far-reaching institutional developments. First, the construction of the Darbar Sahib (present-day "Golden Temple") amidst the sacred pool of Amritsar was the momentous achievement of his building program. It acquired prominence as the central place of Sikh worship. The founding of new towns of Tarn Taran, Sri Hargobindpur and Kartarpur (Jalandhar) in rural areas saw large number of converts from local Jat peasantry. In this context, Louis Fenech makes an interesting observation that "the construction of cultural artifacts such as buildings and cities resonating with power and authority of the Mughal darbar ["court"] and the Mughal sovereign himself as the apotheosis of the divine, refashioned to serve both the spiritual and economic needs of Guru Arjan and the growing Sikh Panth" (Fenech 2008, p. 66). Second, Guru Arjan inherited a rich and substantial scriptural corpus that he took upon himself to systematize and organize into what became the Guru Granth Sahib, the key marker of Sikh identity for generations to come. Indeed, the making of Sikh scripture was a massive editorial undertaking, which ended in 
the establishment of the Adi Granth in 1604. The manuscript bearing this date is still in existence at Kartarpur, in the Jalandhar District of Punjab. That is why it is commonly known as Kartārpur Pothī ("Volume"). Third, the installation of the Sikh scripture in the Darbar Sahib in 1604 enhanced its centrality in Sikh life. As a result, the city of Ramdaspur emerged as a new "power center" in its own right. Finally, by the end of 16th century, the Sikh Panth had developed a strong sense of independent identity, which is quite evident from Guru Arjan's assertion, "We are neither Hindū nor Musalmān" (GGS, p. 1136).

The author of Dabistan-i-Mazahib ("The School of Religions"), a mid-17th-century Persian historian, Maubad Zulifkar Ardastani, attests that by "the reign of Guru Arjan Mal, [the Sikhs] became very numerous. Not many cities remained in the inhabited region, where the Sikhs had not settled in some number" (Grewal and Habib 2001, p. 66). The same author provides us with an important insight into the regular system of voluntary offerings collected by the masands ("deputies"). He does so from purely an economic angle by comparing these contributions of loyal Sikhs, bhet ("offering") and nazar ("gift"), with the bāj ("tribute") levied by the Mughal rule. Later theorists, however, seized upon this idea to suggest political motives in the religious work of the Sikh Gurus (Singh 2006, p. 45). To the skeptical mind all this appeared to be the stuff of sovereignty (Fenech 2008, p. 65). In fact, the growing strength of the Sikh movement attracted the unfavorable attention of the ruling authorities because of the reaction of Muslim revivalists of the Naqshbandi order in Mughal India. There is clear evidence in the compositions of Guru Arjan that a series of complaints were made against him to the functionaries of the Mughal state, giving them an excuse to watch the activities of the Sikhs. Unsurprisingly, on 4 November 1598, Emperor Akbar officially visited the Sikh court at Goindval. He listened to the devotional singing in the congregation and was greatly impressed by "the recitation of the Hindi verses that had been composed by Bābā Nānak for expounding the knowledge of God" (Singh 2006, p. 21). He acknowledged Guru Arjan's "great store of spiritual love" and the selfless service of the Sikhs (Singh 2006, p. 19). At the Guru's instance, Akbar remitted the annual revenue of the peasants of the district who had been hit hard by the failure of the monsoon. He was genuinely impressed with what he saw at Goindval and gave his explicit approval to the work done by Guru Arjan. The emperor's nod to his philanthropic work put those Mughal officials who were involved in the machinations of Prithi Chand and his followers on guard. As a result of tax remission, Guru Arjan's popularity skyrocketed in the rural peasantry of the Punjab.

The liberal policy of Emperor Akbar may have sheltered Guru Arjan and his followers for a time, but it could not remove the nefarious designs of the Guru's enemies for good. The effect of his policy of religious tolerance did not last long after his death in October 1605. As a matter of fact, his liberal approach was much despised by many of his more aggressive co-religionists, particularly the protagonists of the Naqshbandi revivalist movement (Singh 2006, p. 150). In the volatile atmosphere of Prince Khusrau's rebellion, Guru Arjan was tortured to death on 30 May 1606 by the orders of Emperor Jahangir (r. 1605-1628). Although the crowning cause of capital punishment was presented as Guru Arjan's alleged blessings to the rebel Prince Khusrau, there were other urgent religious, socio-cultural, and economic factors that contributed in the final judgment of the absolute monarch. The Mughal administrators of Lahore who had been carefully monitoring the Sikh movement for a number of years found their opportunity to finally act against the Guru. They moved swiftly to eliminate Guru Arjan and cripple the rapidly growing Sikh movement. Through their machinations, they purposefully kept the Guru's execution from public view in an attempt to absolve the state by subverting the understanding of the Sikh community.

\subsection{Mounting a Non-Violent Protest March: Chaunikī Chärhnī}

Guru Arjan's execution empowered his followers to stand for the ideals of truth, social justice and fearlessness more boldly. A radical reshaping of the Sikh Panth took place after his martyrdom. His son and successor, Guru Hargobind (1595-1644), signaled the formal process when he traditionally donned two swords symbolizing the spiritual $(p \bar{\imath} r \bar{\imath})$ as well as the temporal $(m \bar{\imath} r \bar{\imath})$ investiture. He also 
built the Akāl Takhat ("Eternal Throne") facing the Darbār Sāhib, representing the newly assumed role of temporal authority. Under his direct leadership, the Sikh Panth took up arms to protect itself from Mughal hostility. According to Bhāī Gurdās, this new martial response was like "hedging the orchard of the Sikh faith with the hardy and thorny kikkar tree" (Vār 25:25). It was meant to achieve a balance between temporal and spiritual concerns. Thus, Guru Arjan's martyrdom became the watershed in Sikh history, contributing basically to the growth of Sikh community self-consciousness, separatism, and militancy.

A distinctive resistance movement in the form of a processional devotional singing (chauinkī chārhni, "mounting or marching of the chaun $k \bar{\imath}$ ") march came into being when Emperor Jahangir put the sixth Guru, Hargobind, into jail in the fort of Gwalior. During the Guru's absence from Amritsar at the time of his internment the elderly Sikh, Baba Buddha (d. 1635), started the first processional chaunki from the Akal Takhat to protest against the Mughal authorities. The author of the Persian Dabistān-i-Mazāhib (1640s) testifies, "during this time the Masands and the Sikhs used to go and bow down to the wall of the fort" (Singh 2011, p. 117). One Sikh would hold a torch (mishāl) of protest, leading the chanting Sikhs to Gwalior. It was the impact of such musical processions from Amritsar to Gwalior that Emperor Jahangir released Guru Hargobind in 1612 much before the completion of the actual imprisonment of twelve years. To commemorate this tradition of protest against the Mughal authorities, Baba Budha laid out a special procedure of the earliest processional chauniki with the blessings of Guru Hargobind. This public musical performance has been followed for the last four centuries and has become an integral part of non-violent Sikh protests. In fact, the modern-day Nagar Kìrtan ('Public Performance of Devotional Singing') parades in different cosmopolitan cities around the world are extended versions of this earlier tradition (Singh 2011, pp. 117-19).

After four skirmishes with Mughal troops, Guru Hargobind strategically withdrew with his armed retinue to Kiratpur in 1634 at the edge of Shivalik Hills in the Hindur territory of a vassal beyond the jurisdiction of the Mughal Empire. Amritsar fell into the hands of the Minās (descendants of Prithi Chand), who established a parallel seat of authority with the support of Mughal officials. Notably, Guru Hargobind designated his grandson Har Rai (1630-1661), Gurditta's younger son, as his successor before he passed away on 3 March 1644. This was done in response to Mughal interference in Sikh affairs because Dhir Mal, Gurditta's elder son, had already established a parallel seat of authority at Kartarpur in Jalandhar District with the help of a revenue-free grant given to him by Emperor Shah Jahan on 29 November 1643. With the original Kartārpur Pothī (1604) in his possession, Dhīr Mal laid claim to the office of Guru. The Mughal emperor had thought of bringing the Sikhs under control by supporting the claims of Dhīr Mal and his followers. The mainline Sikh tradition, however, continued to honor the decision of Guru Hargobind.

Guru Har Rai designated his youngest son, Har Krishan (1656-1664), to be his successor before he passed away at Kirtapur on 6 October 1661. This decision was a direct challenge to Emperor Aurangzeb (r. 1658-1707), who had kept the eldest son Ram Rai as hostage in Delhi on the assumption that Ram Rai would be the heir apparent of Guru Har Rai and could be manipulated into bringing the Sikhs under control. The emperor summoned the young Guru to Delhi through Raja Jai Singh of Amber. Anticipating that the emperor would insist that he demonstrate miraculous feats, Guru Har Krishan refused to meet with him in person. Meanwhile, an epidemic of smallpox was raging in the city of Delhi, and the Guru came out of Raja Jai Singh's bungalow to tend the sick. During the service of healing the sick, Guru Har Krishan was himself afflicted with the disease of smallpox. He made the pronouncement of designating his successor as "Baba Bakale," meaning that the next Guru would be found in the town of Bakala, in effect referring to his great-uncle Tegh Bahadur (youngest son of Guru Hargobind), who lived there in the town of Bakala at that time. Guru Har Krishan passed away on 30 March 1664, thus denying the emperor any opportunity to interfere in the designation of a rightful successor in the mainline Sikh tradition.

During the period of the ninth Guru, Tegh Bahadur (1621-1675), the increasing strength of the Sikh movement in the rural areas of the Malwa region of the Punjab once again attracted the hostility 
of Mughal authorities. The Guru encouraged his followers to be fearless in their pursuit of a just society: 'He who holds none in fear, nor is afraid of anyone, is acknowledged as a man of true wisdom' (GGS, p. 1427). In doing so, Guru Tegh Bahadur posed a direct challenge to Emperor Aurangzeb who had imposed Islamic laws and taxes on non-Muslims. According to an earliest narrative, when a group of Hindu pandits ('scholars') from Kashmir asked for the Guru's help against Aurangzeb's oppressive measures, he agreed to do whatever was necessary to defend their rights to wear their 'sacred threads and frontal marks' (Dasam Granth/DG, p. 70). A message was sent to the emperor saying that if Guru Tegh Bahadur could be persuaded to accept Islam, the Hindus would convert as well. Accordingly, the Guru was summoned to Delhi, and when he refused to abandon his faith he was publicly executed on 11 November 1675. In a recent study on Aurangzeb, Audrey Truschke provides an imperial perspective that the emperor "had the Sikh guru Tegh Bahadur executed in 1675 for taking up arms against the Mughal state" (Truschke 2017, p. 38). Later, she acknowledges that the execution is not mentioned in any Persian texts from Aurangzeb's period but still she speculates that it happened "for causing unrest in the Punjab" (ibid., p. 54). Surely, Guru Tegh Bahadur's message of resistance against state oppression was the sufficient reason for his elimination even though there is no contemporary evidence that he took up arms against the Mughal state.

\subsection{Institutionalizing the Khalsa: An Army of Warrior Saints}

If the martyrdom of Guru Arjan had helped to bring the Sikh Panth together, the second martyrdom of Guru Tegh Bahadur helped to make 'human rights and freedom of conscience' central to its identity. In this context, Wilfred Cantwell Smith has aptly remarked that "the attempt forcibly to convert the ninth Guru to an externalized, impersonal Islam clearly made an indelible impression on the martyr's nine-year-old son, Gobind, who reacted slowly but deliberately by eventually organizing the Sikh group into a distinct, formal, symbol-patterned, boundaried community" (Smith 1981, p. 191). Tradition holds that the Sikhs who were present at the scene of Guru Tegh Bahadur's execution shrank from recognition, concealing their identity for fear they might suffer a similar fate. In order to respond to this new situation, the tenth Guru, Gobind Singh (1666-1708), resolved to impose on his followers an outward form that would make them instantly recognizable. He restructured the Sikh Panth and instituted the Khalsa ("pure"), an order of loyal Sikhs bound by common identity and discipline. On Vaisakhi Day 1699 at Anandpur, Guru Gobind Singh initiated the first so-called 'Cherished Five' (panj piare), who formed the nucleus of the new order of the Khalsa. These five volunteers who responded to the Guru's call for loyalty, and who came from different castes and regions of India, received the initiation through a ceremony that involved sweetened water (amrit) stirred with a two-edged sword and sanctified by the recitation of five liturgical prayers.

Guru Gobind Singh symbolically transferred his spiritual authority to the Cherished Five when he himself received the nectar of the double-edged sword from their hands and thus became a part of the Khalsa Panth and subject to its collective will. In this way, he not only paved the way for the termination of a 'person' holding the office of Guru but also abolished the institution of the elite appointed deputies (masands), who were becoming increasingly disruptive. Several masands had refused to forward collections to the Guru, creating factionalism in the Sikh Panth. In addition, Guru Gobind Singh removed the threat posed by competing seats of authority when he declared that the Khalsa should have no dealings with the followers of Prithi Chand (Mīnās), Dhir Mal (Guru Har Rai's elder brother, who established his seat at Kartarpur, Jalandhar), and Ram Rai (Guru Har Krishan's elder brother, who established his seat at Dehra Dun) (Singh 2017, p. 75). With the creation of the Khalsa, the Guru infused a new spirit among his warrior-saints, who were ready to fight against injustice and tyranny. Thus, in transforming Sikhs into a self-governing warrior group, the tenth Guru set in motion a profound change in the political and cultural fabric of the Mughal province of Punjab (Dhavan 2011, p. 3). Most instructively, his army was never to wage war for power, for gain or for personal rancor: "The Khalsa was resolutely to uphold justice and to oppose only that which is evil" (McLeod 1997, p. 105). 
Following the mìrī-pìri tradition of Guru Hargobind, Guru Gobind Singh assumed characteristics of a spiritual leader as well as a temporal ruler who had the specific responsibilities to protect righteousness (dharam). Unsurprisingly, waging battle was part of his dharmic responsibility. The majority of the narrative of his life is devoted to detailed description of a series of battles. Indeed, Guru Gobind Singh was an able spiritual and political leader who maintained a court at Anandpur, and who led an army in many battles throughout his life. In this context, Hardip Singh Syan makes an interesting observation that the tenth Guru had transformed his estate into something more sizable and converted himself into a local monarch: "Unlike previous Gurus, Guru Gobind Singh's power was profoundly political, and given the heightened geo-political sensitivities of late 17th-century Mughal India, it was seen as overtly threatening to Mughal authority" (Syan 2013, p. 157). The creation of the Khalsa by Guru Gobind Singh was unique in two senses: first, it invited all Sikhs to join the Order of the Khalsa regardless of their background, and second, it had a coherent vision of political sovereignty. The tenth Guru proclaimed: "The Khalsa shall rule, no enemy shall remain. All who endure suffering and privation shall be brought to the safety of the Guru's protection" (Tanakhāh-nāmmā, cited in(McLeod 1989, p. 64). All Sikhs were encouraged to become warriors of righteousness (dharm) engaged in a struggle against tyranny. Thus, Guru Nanak's fundamental message of human equality, self-respect, dignity, and fearlessness found its practical expression in the lived experience of the Khalsa (Singh 2017, p. 76).

Before he passed away in 1708, Guru Gobind Singh placed the spiritual and temporal authority (jama) within the collective body of the Khalsa, emphasizing the corporate sovereignty of the Sikh Panth. He also closed the Sikh canon by adding a collection of the works of his father, Guru Tegh Bahadur, to the original compilation of the Adi Granth. Most significantly, he terminated the line of personal Gurus, and installed the Adi Granth as the eternal Guru for Sikhs. Thereafter, the authority of the Guru was invested both in the scripture (Guru Granth) and in the corporate community (Guru Panth). The compound term Sarbat Khālsā ("Entire Khālsā") originated in the 18th century to describe the temporary unity accomplished by the linking of different Sikh principalities (misls) for some shared purpose, such as campaigns against the armies of Mughals and Afghan invaders. Finally, in 1799, Ranjit Singh (1780-1839) succeeded in unifying the Punjab, taking control of Lahore and declaring himself Maharaja. For the next four decades, the Sikh community enjoyed more settled political conditions, and with territorial expansion as far as Peshawar in the west, people of different cultural and religious backgrounds were attracted into the fold of Sikhism. The political sovereignty in the litany "The Khalsa shall rule!" had become the destiny of the Khalsa, and it was fulfilled in the time of Maharaja Ranjit Singh. After the death of the Maharaja in 1839, however, his successors could not withstand the pressure exerted by the advancing British forces. After two Anglo-Sikh wars, in 1845 and 1849, the Sikh kingdom was annexed to the British Empire.

\section{Sikhs in the British Raj (1849-1947)}

With the loss of the Punjab's independence, the Sikhs were no longer the masters of their own kingdom. The introduction of the British administration into the Punjab at the time of annexation in 1849 brought profound changes in the Punjabi society. First, the colonial rulers introduced a large measure of bureaucracy and the rule of law, which established a new kind of relationship between the individual and the state. The 'paternal' rule of the early decades was eventually replaced by the 'machine rule' of laws, codes and procedures (Grewal 1990, p. 128). Second, the British introduced a worldview grounded in the secular, modernizing ideology of the Enlightenment. Third, the British sought to cosset and to control the Sikhs through the management of the Golden Temple and its functionaries (Kerr 1999, p. 153). In this context, the British even sidestepped the dictates of statutory law which required them to maintain "the separation of secular and religious matters, neutrality in the treatment of religious communities and the withdrawal from involvement in religious institutions" (ibid., p. 164). Indeed, for the alien British, the need to control the Golden Temple was the greater. Finally, they put a legal ban on carrying of weapons. This decision was meant to disarm the Khalsa who had fought valiantly against the British in two Anglo-Sikh wars in 1845 and 1849. 
Here, it is instructive to closely look at Harjot Oberoi's major arguments in The Construction of Religious Boundaries (Oberoi 1994), relating to the socio-religious movement among the Sikhs in the colonial period based upon the ethnographic approach and a Foucauldian vision of the 'new episteme' fashioned by the Singh Sabha. For him, the Singh Sabha consisted of two components: the Sanatan and the Tat Khalsa ("Essential Khalsa"). Sanatan Sikhs accepted the authority of the Vedas and Puranas in addition to the Sikh scriptures, thereby believing in incarnations and the ideas of pollution and purity based upon the caste system. The Tat Khalsa, on the other hand, rejected all Hindu accretions prevalent in the Sikh society in the 19th century. Applying a social scientific method of analysis, Oberoi argues how the Tat Khalsa, the most influential segment of the Singh Sabha movement, succeeded in eradicating all forms of religious diversity at the turn of the century and in establishing uniform norms of religious orthodoxy and orthopraxy (Oberoi 1994, p. 25). As a consequence of the success of the Tat Khalsa reformers, Sikhs in the early 20th century came "to think, imagine and speak in terms of a universal community of believers united by uniform rites, symbols and scripture" (Oberoi 1988, p. 154).

In his analysis, however, Oberoi tilts the balance of evidence artificially in favor of Sanatan Sikhism. There is no doubt that some Sikhs did embrace Hindu practices in the 19th century. By projecting this backward, Oberoi seems to imply that Sikh identity was always predominantly fluid, with free mixing of Sikh and Hindu practices. This is questionable. From as early as the period of Guru Arjan, Sikhs clearly were encouraged to think of themselves as a distinct community. Not surprisingly, J. S. Grewal criticizes Oberoi's view of the Singh Sabha "as a new episteme arising out of praxis" since it precludes the "possibility of any meaningful linkages with the past" (Grewal 1997, p. 73). Further, Oberoi's division of the Singh Sabha into 'Sanatan tradition' and the 'Tat Khalsa' is problematic. There were three strands of thinking represented by three prominent individuals. First, Khem Singh Bedi of Amritsar Singh Sabha supported the centrality of the Singh identity and the significance of the Khalsa initiation, but he also stressed the idea of divine incarnations, the need for a living guru, and the indivisibility of Sikh and Hindu society. Second, Gurmukh Singh of Lahore Singh Sabha held the middle position that the activities of the ten Gurus and the Guru Granth Sahib serve as the ultimate source of Sikh belief and practice. The Singh identity was the ideal but those who had not undergone the Khalsa initiation were an indivisible part of the Sikh Panth as long as they recognized the Guru Granth Sahib as the 'Eternal Guru'. Sikhs constituted a distinct community and the question of Hindu-Sikh relationship was a redundant issue. Third, the position of Teja Singh of Bhasaur Singh Sabha was far more radical. He claimed that anyone who has not undergone the Khalsa initiation should have no place within the Sikh Panth. In his vision of 'orthodoxy', the periphery was to be simply excised, and raising the issue of Hindu-Sikh relationship was an insult to the Sikhs. In the beginning of the 20th century, "Bedi and Bhasaur were eventually sidelined" (Mann 2004, p. 63) and Gurmukh Singh's middle position of the Tat Khalsa achieved general acceptance, both in institutional and ideological terms.

The British developed their theory of the "martial races" of India during the latter part of the 19th century, in accordance with which they classified Sikhs as a martial race, thus favoring them as army recruits with the requirement of turban and Khalsa initiation. Notably, during the British Raj, the ways and means of the master discourse came to be mimicked by the native Punjabis in ultimately undercutting the colonialist agenda. The new cultural elite among the Sikhs was moving to the apex of a more homogeneous, less 'oral and popular' oriented, textually focused 'syndicated' tradition that roughly corresponded to the typologies of 'religion' furthered by the colonists. The Khalsa of the Singh Sabha reformers was both old and new. The emerging Tat Khalsa identity espoused by the dominant wing of the Singh Sabha had been forged, admittedly from the pre-existing ores, in the crucible of colonial encounter. In addition to the economic and military policy of the British, there were other elements, which meshed together to produce a great impact on the emerging Sikh identity. These additional elements in the larger colonial context were new patterns of administration, a new technology, a fresh approach to education, the entry of Christian missionaries, and the modernist perspective based on the scientific paradigm of the Enlightenment. All these factors produced a kind 
of neo-Sikhism, characterized by a largely successful set of redefinitions in the context of the notions of modernity and religious identity imposed by the dominant ideology of the colonial power closely associated with Victorian Christianity. The Singh Sabha ideologues employed Protestant categories of Christian missionaries to redefine Sikh concepts. As such, modern Sikhism became a well-defined 'system' based on a unified tradition and the Tat Khalsa understanding of Sikh identity became the norm of orthodoxy. In a recent study, Arvind-Pal Mandair described the impact of colonial rule on the Sikh tradition as follows: "In the process of projecting themselves as a legitimate body in the public sphere governed by British law, the earlier principle of heteronomic sovereignty was overlain, and to some extent displaced, by modernist principle of autonomic sovereignty which was essential for converting the Panth into a nationalized community (or qaum) characterized by the notion of a people with its proper religion (Sikhism), their own language (Punjabi) and a geographical territory or homeland they could call their own (Punjab)"(Mandair 2015, p. 119).

In the beginning of the 20th century, the two leading wings of the Singh Sabha reformers from Lahore and Amritsar merged into one with the establishment of Chief Khalsa Diwan (CKD) in 1902, mainly due to the need for greater political coordination in the face of a more aggressive adversary, the Arya Samaj, as the principal agent of political Hinduism in Punjab. The CKD's main achievement was to get an important constitutional change in the form of legal recognition of the distinctive Sikh wedding ritual in the Anand Marriage Act of 1909. However, the soft 'constitutional politics' of the urban elites of the CKD was soon replaced by the 'politics of agitation' followed by the more robust Akalis from the rural backgrounds. In the 1920s, the Akalis helped to re-establish direct Khalsa control of the major historical gurdwaras, many of which had fallen into the hands of corrupt mahants ('custodians') supported by the British. The Akali movement began in 1920 as a non-violent agitation by constituting a representative body of the Sikhs known as the Shiromani Gurdwara Prabandhak Committee (SGPC: "Chief Management Committee of Sikh Shrines"). This agitation is sometimes described as the "Third Sikh War" of 1920-1925, although it is better known as the Gurdwara Reform Movement. The Tat Khalsa reformers demanded control of Sikh shrines in opposition to the British supported mahants and pujāris ('priests'). The last gasp effort of the British to manipulate the Sikhs via management of the Golden Temple and its priests proved an ignoble failure in 1919 when General Dyer's invited visit to the Temple failed to pacify the Sikhs. The Akali answer was given in the non-violent agitations over the Nankana Tragedy, Keys Affair, at Guru-ka-Bagh, at Jaito, and elsewhere:

\subsection{Nankana Tragedy}

An attempt to secure Gurdwara Nankana Sahib, the richest of all the gurdwaras, liberated from a notorious mahant was made on 20 February 1921. All the 150-jatha members were butchered and burnt alive by the mahant's hired goons. The next day, when 2200 Sikhs marched to liberate the gurdwara, the authorities relented, and the Commissioner of Lahore handed over the keys to the SGPC President. The SGPC did not co-operate in the inquiry and prosecution of the perpetrators of this horrible crime on M. K. Gandhi's appeal, resulting in mild punishments to the mahant and his hired ruffians (Singh 2014, p. 331).

\subsection{Keys' Affair}

Another Akali agitation began when Deputy Commissioner of Amritsar took away the keys of Golden Temple's treasury from Sunder Singh Ramgarhia, government-appointed Sarbrah ("Manager") and Vice-President of the SGPC on 7 November 1921. SGPC officials and other Sikhs were arrested and prosecuted for discussing the prohibited "Keys' Affair". Non-violent Sikh agitation and non-co-operation followed by the SGPC call to completely boycott the Prince of Wales' visit to India compelled the government to hand over the keys to the SGPC President and release Sikhs jailed during agitation on 11 January 1922. The "First decisive battle for India's freedom," in M. K. Gandhi's words, was thus "won" (Singh 2014, p. 331). 


\subsection{Guru-Ka-Bagh Morcha}

This agitation began in August 1922. The Sikhs were arrested for cutting wood from gurdwara land on the basis of a backdated complaint obtained by the authorities from the mahant who had already surrendered the gurdwara and attached property to the SGPC. The SGPC sent a jatha daily under the oath of non-violence from the Akal Takht. The jatha members and other volunteers were brutally beaten to unconscious. The police atrocities on non-violent Akalis won sympathy and admiration for them at the national and international level. Failing to browbeat the struggle, the government extricated itself out and released all the 5605 persons including 35 SGPC members in November 1922 (Singh 2014, p. 331).

\subsection{Jaito Morcha}

The SGPC passed a resolution in August 1923 to sympathize with the Maharaja of Nabha who was compelled to abdicate by the government. Relations with authorities were strained further when the police disrupted an Akhand Päth ("continuous reading") of Guru Granth Sahib at Jaito. To assert the sanctity of the ritual, jathas of 25 Sikhs each were sent from Akal Takht after administering an oath of non-violence. They were brutally beaten on their entry in Nabha state and left in far-flung areas (Singh 2014, p. 331).

The Akali campaign was finally terminated by the drafting and passing of the Sikh Gurdwaras Act of 1925, under which control of all gurdwaras passed to the Shiromani Gurdwara Prabandhak Committee (SGPC). The Akalis were the forerunners of the modern political party known as the Akali Dal ('army of the immortal'). Control of the gurdwaras gave the SGPC enormous political and economic influence. In the course of time, the SGPC became the 'authoritative voice' of the Sikhs. As a democratic institution, it represented the majority Sikh opinion and provided the Akalis political muscle in a dangerously factionalized Punjab. The gurdwaras as autonomous Sikh spaces became powerful symbols of Sikh sovereignty and encouraged Sikhs to proclaim a separate national identity (qaum). However, Akalis did not define this nationhood in exclusive terms, but rather emphasized its place within the community of nations that constituted Indian political milieu. However, the Indian National Congress (INC) made a transition from communitarian nationalism advocated by such leaders as M. K. Gandhi to a secular nationalism, thereby redefining itself in terms of Western European secularism, which recognized political representation only on the basis of the separation of religion from the secular state (Mandair 2013, pp. 96-97; Mandair 2014, p. 79). The INC's privileging of secular nationalism undercut Sikh aspirations for political autonomy. In April 1940, Vir Singh Bhatti of Ludhiana wrote a pamphlet demanding "Khalistan" as a buffer state between India and "Pakistan" to oppose the "Pakistan Resolution" of the Muslim League. The Akalis, however, rejected this idea on the grounds that it was a theocratic model. They were looking for alternatives to buttress their claims for a measure of self-determination.

As the specter of partition was on the horizon of Indian politics in 1942, the mission of Stafford Cripps appeared to concede the demand of Pakistan in principle. The precarious situation of the Sikhs in the Punjab became obvious because of their thin demographic distribution over the province. They put forward the "Azad Punjab Scheme", which the Akalis popularized for about two years as an alternative to Cripps Proposals. For the Sikhs, a separate Sikh state or Khalistan would be synonymous with an area where no single community will be in absolute majority. They invoked property and religious/historical associations as the criteria of partition and talked of "Sikhistan" with the option to join either Hindustan or Pakistan to extort the largest possible concessions in terms of territory. In this context, G.E.B. Abell wrote a confidential document on 5 June 1946: "If the Sikhs raise the question of a separate Sikh state such as KHALISTAN, the answer is that it would have been quite impossible for the Cabinet Mission to consider such a scheme in view of the fact that the Sikhs would be a small minority in every area of the districts which it had been proposed to include in such a territory" (India Office Library, London, File R/3/1/132, folio 51; cited in Nahal 2011, p. 140). Under these circumstances, Jawaharlal Nehru gave a solemn assurance in 1946 that there was nothing objectionable in the Sikhs 
having an area demarcated in North West of India, where they could "enjoy glow of freedom." With the largest proportion of the Sikhs opting for India in 1947, the "East Punjab" became, in a sense, a gift of the Akalis to the Indian Union (Grewal 1990, pp. 178-80).

\section{Sikhs in Post-Colonial India (1947-Present)}

In 1947, the British withdrew from India and the subcontinent was partitioned to create two independent republics of India and Pakistan. Partition was especially hard for the Sikhs because it split the Punjab into two. Most of the 2.5 million Sikhs living on the Pakistani side fled as refugees; though many settled in the new Indian state of Punjab, some moved on to major cities elsewhere in India. Rehabilitation and settlement resulted in a significant change in the demographic pattern in the Punjab. In 1951 the Sikhs formed about 35 percent of total population of the state, while the Hindus represented the majority with over 62 per cent. After partition, the Sikh members of the Constituent Assembly refused to sign the draft constitution to be adopted by the people of India on 26 January 1950. They resented the fact that the Constitution of India did not recognize the independent identity of the Sikhs and failed to establish a separate personal law for them. This was hardly an auspicious beginning for the Sikhs in post-independence India. The Congress government did not honor the solemn promises given to ensure Sikh self-determination before independence. The Sikhs also resented that all state boundaries in the new Indian union except those of the Punjab were redrawn based on the mother tongue of the majority of residents. Thus began the Sikh struggle for Punjabi Sūba ("Province") in the 1950s and early 1960s.

\subsection{Punjabi Sūbā Agitation}

As a minority community, the Akalis realized that any politics based on religious identity will not succeed. For them, the only way forward in the political sphere was to raise the issue of Punjabi language spoken by both Sikhs and Hindus in the Punjab as the marker of their identity. They asserted that the demand for a linguistic state was democratic, secular, and beneficial to both Sikhs and non-Sikhs alike. But the urban Hindus led by the Jan Sangh ("People's Organization" with its Arya Samaj leanings) feared that this demand was only a ruse for creating a state with Sikh majority. Thus, the first two decades after the partition were marked with Punjabi Sūba ("Province") agitation of the Akalis, resulting in the heightened political rivalries between the Akali Dal and the ruling Congress Party. More than 50,000 Sikhs went to jail in this non-violent movement. It was only after the major contribution of the Sikhs in the Indo-Pakistan war of 1965 that the central government became receptive to the Akali demand. The demographic pattern changed with the creation of a 'Punjabi Province' on 1 November 1966 as the result of the reorganization of the state into the Punjab and Haryana on linguistic grounds. The Sikhs formed the majority with over 62 percent in the new Punjab state. Eventually, the Akali Dal was able to wrest political power in the Punjab with the help of the erstwhile Jan Sangh and other allies. Of course, the central government at New Delhi would frequently topple their ministry to bring the Congress rule back in the state (Singh 2014, p. 30).

\subsection{The Anandpur Sahib Resolution (ASR)}

A sense of injustice and discrimination dawned upon the Akalis when many Punjabi villages were kept out of the Punjab at the time of reorganization of the state. The central government made the new capital of Chandigarh a union territory to be shared by both the Punjab and Haryana and kept complete control over river-waters, irrigation projects and power in Punjab. Nevertheless, the 'green revolution' of 1960s and 1970s made the Punjab the breadbasket of India. In 1973, the main political party of the Sikhs, the Akali Dal, passed the Anandpur Sahib Resolution (ASR), demanding increased autonomy for all the states of India. Over the following years, relations with the Indian government became increasingly strained as a result. The ASR for more autonomy for all Indian states afforded Prime Minister Indira Gandhi the opportunity to depict the Akali Dal as 'separatist' organization and to present herself as India's savior in much the same way as Jawahar Lal Nehru had earlier branded the 
demand for a Punjabi Sūba as 'communal'. Although the demands of the ASR were primarily secular, the language used to articulate those demands enabled Indira Gandhi and the Punjab Congress Party to interpret it as a religiously inspired secessionist document (Shani 2008, p. 53). The most controversial wording of "the pre-eminence of the 'voice of Khalsa' in the Panth" in the ASR sub-preamble gave credence to more sectarian elements within internal Sikh politics. Using the political strategy of accusations of treason by putting the Akali Dal in the 'secessionist' trap, Indira Gandhi wanted to consolidate her power.

\subsection{Akali Protest against National Emergency}

When Indira Gandhi was unseated by the verdict of Allahabad High Court, she immediately declared a state of emergency and the suspension of parliamentary democracy in June 1975. Interestingly, the Akali Dal was the most successful regional party in India, which opposed the promulgation of the draconian Maintenance of Internal Security Act (MISA), giving the police the power to arrest and to detain people without trial. The Congress party was desperate to break up the formidable Akali Dal, which had sent 40,000 volunteers to court arrest against the emergency. It was, therefore, looking for someone who could challenge and put an end to the traditional Akali hegemony over Sikh affairs. Irritated by the Sikh response, Indira Gandhi started to directly intervene in the Sikh 'political system' (Shani 2008, p. 53). The Congress party promoted Sant Kartar Singh Khalsa who led the largest procession in Delhi to observe the 300th anniversary of Guru Tegh Bahadur's martyrdom, while the Akali leaders were in jail. Unfortunately, he died in a road accident on 16 August 1977. Before his death, he named Sant Jarnail Singh Bhindranwale as his successor who was formally elected at a bhog ('completion' of a continuous reading of the Guru Granth Sahib) ceremony at Mehta Chowk on 25 August 1977. When the emergency was lifted in 1977, Indira Gandhi's Congress was completely routed in parliament elections, bringing a coalition government of Bhartiya Janata Party (BJP) for the first time. The Akali Dal came to power in the Punjab and joined the government at the center as a coalition partner (Singh 2016, p. 186).

\subsection{Dharam Yudh Morchā ("Agitation of Righteous War")}

As a result of the Nirankari-Sikh clash in Amritsar in 1978, Sant Jarnail Singh Bhindranwale arrived on the central stage of political scene. In the following year, he was promoted and supported by the Congress in SGPC elections, although his Dal Khalsa party won only four seats. To a certain extent, this initial alliance of Congress with Bhindranwale was fruitful, as the Akali administration lost control of the state government in the 1980 elections. Indira Gandhi's Congress also won mid-term elections at the center on the slogan of 'unity and integrity' of India. However, Bhindranwale proved to be what Shani has termed a 'Lion of the Punjab' that Indira Gandhi could not tame (Shani 2008, p. 55). The assassination of Lala Jagat Narain in September 1981 pointed to Bhindranwale as a possible suspect. Having failed to arrest him at Chando Kalan in Haryana, the Punjab Police set fire to his vans and burnt Bhindranwale's sermons and several copies of the Gurū Granth Sāhib. This was an affront to Bhindranwale's sensibilities. He voluntarily offered himself for arrest at Mehta Chowk on 20 September 1981. After intensive investigation, he was released because of lack of evidence. This resulted in the meteoric rise of the charisma of Bhindranwale who dissociated himself from the Congress party, demonstrating that he was his own man. Subsequently, he moved to Guru Nanak Nivas in the Golden Temple Complex to join hands with the Akalis in the 'agitation of righteous war' (dharam yudh morchā) against the central government in 1982. He repeatedly exhorted his followers that 'an armed Sikh should not kill the unarmed' (Das 1995, p. 132). About 30,000 Sikhs took oath at the Akal Takhat to court arrest as part of this ongoing struggle. Two more batches of Akali Jathas, making a total of 100,000 volunteers, courted arrest on 27 April and 12 May 1983 (Singh 2016, p. 186).

Indira Gandhi sought to meet the Akali 'threat' to India's territorial integrity by further encouraging its separatist tendencies in an attempt to split the movement and subsequently crush it (Shani 2008, p. 55). As part of this strategy, a wedge between the Hindus and the Sikhs in the 
Punjab was to be created. The undercover agents of 'Third Agency' posing as armed 'Sikh militants' massacred Hindu passengers in a hijacked bus going to New Delhi in 1983 (Sidhu 2014). Bhindranwale and Akali leaders condemned this horrible event alike. The center imposed the President's rule in October 1983. Undoubtedly, the imposition of President's rule marked the beginning of a resort to what Gurharpal Singh has termed 'violent control' which exposed the limitations of Indira Gandhi's variation of her father's strategy of 'hegemonic control'. Accordingly, the Nehruvian approach consisted of 'disarticulating Sikh ethno-nationalism through accommodation, co-option, symbolic agreements, and subsequently, non-implementation of such agreements'. Indira Gandhi's 'innovations included a more overt use of violent control mechanisms with a search for an alternative hegemonizing ideology in Hindu revivalism' (Singh 2000, p. 110).

Indian media gave excessive coverage to Bhindranwale, to the extent that his presence soon overshadowed that of the Akalis. By late 1983, he had grown powerful enough to challenge them directly by moving into the Akal Takhat accompanied by militant organizations such as All India Sikh Student Federation led by Amrik Singh, and the Babbar Khalsa. Once lodged into the Akal Takhat, as Mandair argues, these organizations began to accumulate weapons in an attempt to counter the brutalities of the Punjab police and Hindu fundamentalists: "This was done under the watchful eye of the authorities who made no attempt to stop stockpiling of weapons, leading many to speculate that the situation had been carefully controlled by intelligence agencies as part of a bigger plan" (Mandair 2013, p. 102). This bigger plan was revealed from the release of confidential documents [dated 6, 14, 23 February 1984]-how UK Prime Minister, Margaret Thatcher, sent SAS ('Special Air Service', a unit of British Army that undertook a number of roles including covert reconnaissance, counter terrorism, direct action, and human intelligence gathering) to advise Indira Gandhi on Indian army plans "for the removal of dissident Sikhs from the Golden Temple" months before the disastrous raid on Amritsar (Singh 2016, pp. 175-76).

By neatly conflating the image of Bhindranwale as the arch 'Sikh terrorist' with the 'Punjab problem', 'Khalistan' and the 'Hindu-Sikh conflict', the whole Sikh community came to be perceived as the enemy within, ready at any moment to collude with the 'foreign hand' of India's arch enemy and neighbor, Pakistan (Mandair 2013, pp. 102-3). It provided a pretext for Indira Gandhi to send the Indian army to attack the Golden Temple Complex on 3 June 1984, on a Sikh holiday when a large number of devotees were commemorating Guru Arjan's martyrdom. The assault that followed-code-named 'Operation Blue Star' — resulted in the deaths of more than 4000 people, including Bhindranwale, as well as the destruction of the Akal Takhat and severe damage to the Golden Temple itself. A few months later, on 31 October 1984, her own Sikh bodyguards assassinated Indira Gandhi. For several days, unchecked Hindu mobs in Delhi and elsewhere killed thousands of Sikhs. As a consequence of these events, 1984 became a turning point in the history of modern Sikhism, precipitating an identity crisis within the Sikh Panth. According to Mark Juergensmeyer, the following decade saw the Sikh religious rebellion marked by bloody encounters between militant Sikhs and the armed forces of the secular state of India (Juergensmeyer 2008, p. 115). Although he justifies his central argument that religion has a peculiar tendency to exacerbate violence, he confounds the distinction between religious and secular violence by his statements like "the secular is a sort of advanced form of religion" (Juergensmeyer 2008, p. 23) and "secular nationalism is 'a religion'” (Juergensmeyer 1993, p. 15). Due to the rise of religious violence in the contemporary world, he maintains that even if religion is not the problem, it is still problematic. Accordingly, religion is often not the cause of conflict, but exacerbates already existing conflicts.

\subsection{Declaration of Independent Sikh State by the Sarbat Khalsa}

The attack on the Golden Temple Complex and thirty-six other gurdwaras in the Punjab simultaneously, and the Sikh pogroms in Delhi and other parts of India gave rise to the belief among many Sikhs that only an independent Sikh state could safeguard their sovereignty. Dispersed militant groups quickly began a war of 'national self-determination'. They assassinated the Akali 
Leader Sant Harchand Singh Longowal shortly after he had signed a 'peace accord' with the Prime Minister Rajiv Gandhi. This effectively made the Akali leaders irrelevant as Sikh politics began to be dictated by the militant groups. In April 1986, a specially convened global meeting of Sikhs (Sarbat Khalsa) was held at the Akal Takhat on Vaisakhi Day in which 80,000 Sikhs participated. They formally passed a resolution of an independent Sikh state, Khalistan, a declaration that concretized the idea of a Sikh nation (qaum) that had been in the making for almost a century, albeit an imagined nation that was in search of statehood (Mandair 2013, p. 103).

Earlier, the idea of Khalistan was floated as part of the strategy to break the Akali hegemony on Sikh politics. It began with a half-page advertisement in the New York Times on 12 October 1971 by Dr Jagjit Singh Chauhan (1927-2007), a former Finance Minister in the Punjab government led by Chief Minister Lachhman Singh Gill, who headed a minority breakaway group of the Akali Dal supported by Congress. Chauhan was a 'hawkish person' who became the self-proclaimed president of the Khalistan Council, asserting that Sikhs were a 'religious, ethnic, and cultural entity, distinct from Hindus that rule India'. A 'nation in our own right,' Sikhs have 'endured persecution and endless suffering at the hands of an intolerant, mercenary majority that rules India-the Hindus' (New York Times, 12 October 1971). Unsurprisingly, functionaries of militant groups in the Sikh diaspora largely financed the armed struggle for Khalistan, especially in Canada, the United Kingdom and the United States. The Indian government reacted to the Sarbat Khalsa resolution of Khalistan by implementing a politics of 'violent control' that further undermined the Akali position and unleashed a vicious counter-insurgency targeting the militant groups throughout Punjab. Conservative estimates suggest that more than 80,000 people (mostly Sikhs, along with some Hindus and others) lost their lives in the Punjab during the decade from 1982 to 1992 (Mandair 2013, p. 104).

\subsection{Current Issues}

The physical elimination of Sikh militants through staged police encounters and military operations allowed the previously discredited moderate faction under the leadership of the former Chief Minister Parkash Singh Badal (b. 1927) to reassert control over the decimated Akali movement and rekindle their anti-Congress alliance with Hindu nationalists (Shani 2008, p. 73). For political purposes, Badal pushed the Akali Dal towards Punjabi rather than Panthic identity. The party realized that it could not secure a share of state power without the support of Hindu electorates. Even after securing a majority of its own in the assembly elections of 1997, the Shiromani Akali Dal (SAD) chose to form a coalition government with the BJP. Since then, their coalition has been based upon urban-rural collaboration "as the support base of the SAD is predominantly rural and that of BJP urban" (Narang 2014, p. 345). The SAD has remained the only political choice for the Sikhs, making Parkash Singh Badal the Chief Minister of the Punjab thrice (1997-2002, 2007-2012 and 2012-2017) after 1984. Earlier, he became the Chief Minister of the Punjab twice (1970-1971 and 1977-1980) but was not allowed to complete his term of five years by the central government. It is no wonder that Badal has maintained complete familial control over the party by removing his vocal opponents tactically through power play.

The complexity of the Sikh situation in India, as Gurinder Singh Mann argues, is underscored by the fact that the top positions within the country, including those of the prime minister, the chief of the Indian army, and chief of the Indian supreme court have been occupied by the Sikhs such as Manmohan Singh (Prime Minister of India, 2004-2014); Joginder Jaswant Singh (chief of the army, 2005-2007); Bikram Singh (chief of the army, 2012-2014), and Jagdish Singh Khehar (chief justice, Supreme Court of India, 2017-2018). He asserts that the Sikh Panth has made peace with its destiny as one of the many communities within the contemporary Indian state. Yet, one has to notice the inauguration of a memorial dedicated to "Sant Giani Jarnail Singh Ji Khalsa Bhindranwale and all other martyrs of the 1984" next to the Akal Takhat in 2012 (Mann 2017, p. 114). It is true that a considerable mythology gathered around Sant Jarnail Singh Bhindranwale during his lifetime. His death during Indian army's assault on the Golden Temple in June 1984 assured that he would always be remembered as a great hero and martyr of the Sikh Panth. 
During the SAD-BJP rule in the Punjab, a series of cases of desecration of the sacred scripture of the Sikhs took place, beginning with the incident of 110 torn pages of the Guru Granth Sahib found early in the morning of 12 October 2015 at Bargari in Fridkot district. This shocking incident was followed by subsequent protests throughout Punjab. During the early morning hours of 14 October 2015, two Sikh protesters were shot dead by the police at Behbal Kalan as the protesters had turned violent, setting a police vehicle on fire. The Sikhs around the world condemned the sacrilegious incidents. On 10 November 2015, a huge gathering of the Sarbat Khalsa at Gurdwara Baba Naudh Singh passed resolutions condemning the Chief Minister Parkash Singh Badal for his failure to arrest the culprits. On 20 November 2015, the Punjab Cabinet proposed to increase the penalty for sacrilege from three years in prison to life imprisonment. The bill was passed on 22 March 2016. However, the real fallout of Bargari sacrilege and Behlbal Kalan firing was the crushing defeat of SAD in the 2017 assembly elections, giving a large majority of 77 seats to Congress. The Akalis won only 18 seats while the Aam Aadmi Party (AAP) managed to win 20 seats.

Much like the Nirankari-Sikh clash of 1978, the Congress staged a comeback by playing with the religious sentiments of the people of Punjab. Even as SAD appears to be on slippery ground and the Badals are facing a tough time, there is no clear alternative to them, as anti-Badal groups among the Sikhs remain completely fragmented. The most recent non-violent protest at Bargari (1 June 2018-9 December 2018) emerged as a rallying point for Sikhs and it was expected that it could present a political alternative. However, the way the agitation (morcha) was lifted without giving any future roadmap only added to the fluidity in the Panthic space (Singh 2019). Moreover, Dhian Singh Mand, a radical of yesteryear and the leader of Bargari Morcha, whose popularity skyrocketed during the agitation, was battling in late 2018 and early 2019 for political relevance because he sabotaged the movement through his backdoor maneuvering with the Congress government.

\section{Conclusions}

The intersection between religion and politics has always been an integral part of the dynamics in the evolution of the Sikh tradition. The seeds of sovereignty sown by Guru Nanak flowered in the form of an ideology of mìrī-pìri for a new religious-political dispensation. As such, what was latent became manifest, and what became manifest awakened the Mughal authorities to a formidable challenge in the thrust of the growing Sikh power (Ahluwalia 1983, p. 144). In the beginning of the 19th century, Rattan Singh Bhangu presented in his Sri Guru Panth Prakash (1810s) the political mission of the Sikh Panth as an indivisible part of its worldview. In his conversations with Captain Murray who was charged with preparing the history of the Sikhs, Bhangu stressed the point that the Sikh Panth had always "preserved the right to sovereignty" (ham rākhat pātishāhi dāavā). He asserted that Baba Nanak was the "master of both spiritual and temporal matters, but in his grace gave the political power to Mir Babur (1483-1530), the founder of the Mughal dynasty" (Dhillon 2004, p. 263). He further claimed that three generations later, Babur's descendants began to misuse their power-the execution of Guru Arjan, and later that of Guru Tegh Bahadur being the concrete examples of this-and forfeited their right to rule as a result of their misdeeds. Guru Gobind Singh decided to "elevate the Sikhs" to the position of rulers and assigned them a visible identity by ordering them to wear their hair uncut and bear weaponry (Mann 2017, p. 117). Thus, the constant recitation of the litany "Khalsa shall Rule!" in the congregational prayer has shaped the perceptions of the Sikhs at different historical junctures. They have invoked the 18th-century traditions of Sarbat Khalsa, heroism, defiance, loyalty and martyrdom in their present-day struggles. What counts is history as a people actually understand it in their living experience, and for most Sikhs that history dwells in the present as well as in the past (McLeod 2000, p. 88).

One recurring theme in the process of Sikh formations has been 'interference' in Sikh affairs by the state, whether it was the Mughal regime or the British Raj or even the Government of India. Most recently, the Shiromani Akali Dal (SAD) has warned its ally BJP against interference in Sikh religious affairs. It strongly objected to an amendment to Section 11 of Sri Hazur Sahib Management Act, which allows the government to elect gurdwara management chief. Even though the BJP claimed no 
attempts were being made to "dilute" Sikh shrines, the Akalis remained defiant. In a series of tweets, SAD spokesperson Manjinder Singh Sirsa accused the BJP of meddling in the affairs of gurdwaras by trying to install its own persons in gurdwara managements: "We can sacrifice the alliance but cannot tolerate interference in the religious affairs of the community." Sikh minorities across the world are feeling agitated over attempts by the BJP to try and interfere in Gurdwara Patna Sahib. We stopped that by petitioning BJP chief Amit Shah. Now attempts are being made by the BJP-led Maharashtra Government to install their own person as head of the board of Gurdwara Takht Hazur Sahib, Nanded. "This cannot be tolerated. Let the BJP be warned. For us MLA/MP posts are not important. For us, the service of the community is important. If they don't stop meddling in our religious affairs, we will be forced to take the extreme step," Sirsa warned in a video message (The Tribune 2019, 31 January 2019). A truce has finally been called between the warring BJP and SAD, after a meeting between BJP president Amit Shah and the Akali Dal president Sukhbir Singh Badal in Delhi. Both the Akali Dal and BJP confirmed that the presidents of the two parties met for almost two hours. During this meeting, Shah is said to have assured Sukhbir that the amendment made in the Act would be withdrawn (Khanna 2019).

In the 20th century, modern governments have continuously redefined the religious-secular distinctions for the purpose of classifying institutions, practices and people as either "religious" or "non-religious." By doing so, the state actors have been "able to redefine and monopolize the meaning of sovereignty, thereby divesting Sikhs of access to their own forms of sovereign consciousness in their enunciations" (Mandair 2015, p. 140). For instance, the original 1950 text of the preamble to the Constitution of India used only the words "sovereign democratic republic." The addition of the terms "socialist" and "secular" came by way of the forty-second amendment to the Constitution Act of 1976, enacted during the national emergency proclaimed by Indira Gandhi from June 1975 through January of 1977 (Larson 1995, p. 10). This was consciously done to promote the Nehruvian model of the religion-secularism divide based upon the modernist assumptions of the West. Unsurprisingly, right-wing Hindus have strongly criticized it as pseudo-secularism.

The highly contentious Article 25 (2)[b] of the Indian Constitution states that "reference to Hindus shall be construed as including a reference to persons professing the Sikh, Jaina or Buddhist religion, and the reference to Hindu institutions shall be construed accordingly." The legal net of 'Hinduism' is cast very widely in the Constitution of India in such a way that it raises the fundamental problem of defining 'Hinduism'. Sikh resentment resurfaced during the 1980s when Akali leader Parkash Singh Badal publicly burned a copy of Article 25 in New Delhi. Both Sikh and Hindu politicians have used popular interpretations of constitutional wording for their own purposes in ensuing confrontation. Therefore, to remove this misunderstanding, the National Commission to Review the Constitution headed by the former Chief Justice of India, Justice M.N. Venkatachaliah, made the following recommendation: "The commission, without going into the larger issue on which the contention is based, is of the opinion that the purpose of the representations would be served if Explanation II to Article 25 is omitted and sub-clause (b) of clause (2) of that article is reworded as follows-(b) "providing for social welfare and reform or throwing open of Hindu, Sikh, Jain or Buddhist religious institutions of a public character to all classes and sections of these religions" (Ramachandran 2002, The Tribune, 3 April 2002). When this amendment to Article 25 is carried out, the Indian Constitution will duly recognize the distinct and independent identity of Sikhism.

One of the significant consequences of contemporary globalization has been to sever the connections between the state-a coercive apparatus of governance defined in terms of its monopoly over organized violence — and the nation — an 'imagined political community' (Anderson 1991) — to the point where 'many national projects today no longer involve an aspiration to acquire their own sovereign state' (Scholte 2005, p. 228). Accordingly, the de-territorialization of nationalism has created a space for the assertion of 'multiple and overlapping sovereignties' (Inayatullah and Blaney 2004). Thus, sovereignty is no longer seen as the absolute and exclusive attribute of territorially demarcated nation-states, but as plural and mobile. Consequently, Shani argues, it may be possible for the Khalsa Panth to escape the long shadow of territoriality cast by 'the myth of Westphalia' and reclaim the sovereignty invested in 
it by Guru Gobind Singh at Anandpur in 1699 without the establishment of Khalistan (Shani 2014, pp. 279-80; Shani 2008, pp. 128-51). Shani's arguments make sense in a global framework based upon the universality of Sikh values. They may not appeal to a fringe group of the Sikhs (whether in the Punjab or in the diaspora) who are still involved in raising the slogan of 'Khalistan' (Singh 2016, pp. 182-83).

Sikh resistance to brutal state structures has always been formidable. When the Akal Takhat, the seat of temporal authority and political power of the Sikhs, was destroyed during Operation Blue Star in 1984, the Government of India swiftly rebuilt it to pacify the Sikhs. The Sikh Panth did not accept the government-built Akal Takhat, and they razed it to the ground and rebuilt it with their own resources. This action was simply meant to preserve their sovereign consciousness. The Punjab crisis was specifically created by the government agencies that acted as 'extended arms' of state machinery to carry out its evil designs. In modern parlance, it is known as 'penetration strategy': "You stand for separation of religion and politics; encourage use of religion in a certain community for political purposes; and then take action against the community for mixing religion and politics" (Grewal 1998, p. 101). In this context, Virginia Van Dyke (2009) has recently provided a summary of competing narratives of the Punjab crisis. The dominant narrative told by the Akali Dal and supported by many academic and journalistic sources focuses on the malfeasance and vindictiveness of the state, more specifically the Congress Party and Indira Gandhi herself. In this narrative, the rise of a militant movement was a creation of Congress in 1978 to successfully destabilize the Parkash Singh Badal government, leading to nearly two decades of strife. In order to defeat the nefarious designs of Congress, so goes the narrative, there is a need for the coalition between the BJP and the Akalis to preserve harmony and reassure the populace of continued peace. This coalition is also necessary in changing the image of the Sikhs as anti-national. In contrast to the above view, there are other narratives that focus on the desire of the Sikhs for autonomy or independence. And there are also opposing viewpoints to the argument that the coalition between the Akali Dal and the BJP is a statesman-like inter-communal alliance to preserve the peace. According to these alternative voices, including from those few and dwindling number of Akalis who do not belong to the Badal faction, the alliance with BJP is completely self-serving on the part of the BJP and Badal and his supporters. These voices are relatively muted due to the widespread desire for peace, along with structural changes that support the main Akali faction's position (Dyke 2009, p. 126).

However, there is still another narrative, one that deserves much more attention than it has received to date, namely a narrative highlighting the ongoing non-violent dimension of Sikh 'militancy'. The representation of Sikhs and Sikhism in violent and militant images has been pivotal in popular understandings of Sikhism since colonial times. Sikh history is indeed replete with the valor of the Sikh warrior in battle. However, there is less attention to the Sikh warrior in equally and perhaps more demanding non-violent actions. For instance, Paul Wallace (2011) makes the point that the Sikhs are not essentially violent but militant where 'militancy' does not mean violence in actions and reactions alone, but also an aggressive and passionate stand for the cause of their religion and the Gurus. Through a study of the development of non-violent militancy, Wallace argues that public demonstrations and political demands through non-violent means have been more successful than violent ones. Three case studies (of the Gurdwara Reform movement from 1920-1925, the Punjabi Suba ('Province') movement from 1947-1966, and movement against the emergency imposed by the Prime Minister Indira Gandhi from 1975-1977) highlight the strengths of non-violent struggles and those of the actors within the Akali Dal. The violence during the 1980s in the Punjab, Wallace argues, is now finding ways of closure through non-violent democratic means, moving away from 'anti-centrism' to 'cooperative federalism'. Conflict resolution can be found through measures of democratic process and accommodating the former militants in a peaceful manner, along with initiating transparency and justice through the state structure (Wallace 2011, pp. 85-101).

In sum, the Sikh life-world intends to overcome the frequently encountered 'religious'/'secular', 'private'/'public' and 'belief'/'practice' binaries of 'Western' traditions. In this context, Ivan Strenski has 
made an important observation that "religion can be both public and a player in the game of political power, where the conventional clichéd assumptions about religion being this so-called 'spiritual' and internal reality do not always square with facts" (Strenski 2010, p. 154). It is no wonder that all the public-private, religion-politics, and church-state dichotomies have come under the powerful critique of postmodern and post-colonial studies. It has been forcefully argued that such dichotomies, rather than describing reality as it is, justify a certain configuration of power.

Funding: This research received no external funding.

Acknowledgments: I am grateful to four anonymous readers and the editor of this special issue for providing me with their critical feedback to revise an earlier draft of this paper. I am equally thankful to the final two readers in the second round of revisions. All the citations from the Guru Granth Sähib are taken from the standard version of 1430-page text. For instance, "GGS 150" refers to the citation on page 150 of the standard volume. Similarly, "DG 70" refers the citation on page 70 of the standard version of the Dasam Granth of 1428-page text.

Conflicts of Interest: The author declares no conflict of interest.

\section{References}

Ahluwalia, Jasbir Singh. 1983. The Sovereignty of the Sikh Doctrine: Sikhism in the Perspective of Modern Thought. New Delhi: Bahri Publications.

Anderson, Benedict. 1991. Imagined Communities: Reflections on the Origin and Spread of Nationalism, 2nd ed. London: Verso.

Axel, Brian. 2004. The Context of Diaspora. Cultural Anthropology 19: 26-60. [CrossRef]

Bajwa, Kulwinder Singh, ed. 2004. Mahimā Prakāś Vārtak. Amritsar: Singh Brothers.

Das, Veena. 1995. Critical Events: An Anthropological Perspective on Contemporary India. Delhi: Oxford University Press.

Dhavan, Purnima. 2011. When Sparrows Became Hawks: The Making of the Sikh Warrior Tradition, 1699-1799. New York: Oxford University Press.

Dhillon, Balwant Singh. 2004. Sri Guru Panth Prakash. Amritsar: Singh Brothers.

Dyke, Virginia Van. 2009. Politics in Punjab. In Sikh Formations: Religion, Culture, Theory. Oxon: Taylor and Francis Online, vol. 5, pp. 125-27.

Fenech, Louis E. 2008. The Darbar of the Sikh Gurus: The Court of God in the World of Men. New Delhi: Oxford University Press.

Fenech, Louis E. 2014. The Evolution of the Sikh Community. In The Oxford Handbook of Sikh Studies. Edited by Pashaura Singh and Louis E. Fenech. Oxford and New York: Oxford University Press, pp. 41-42.

Fisher, Elaine M. 2017. Hindu Pluralism: Religion and the Public Sphere in Early Modern South India. Oakland: The University of California Press.

Grewal, Jagtar Singh. 1990. The New Cambridge History of India: The Sikhs of the Punjab. Cambridge: Cambridge University Press.

Grewal, Jagtar Singh. 1997. Historical Perspectives on Sikh Identity. Patiala: Punjabi University.

Grewal, Jagtar Singh. 1998. Sikh Identity, the Akalis and Khalistan. In Punjab in Prosperity and Violence. Edited by J. S. Grewal and Indu Banga. New Delhi: Manohar Publishers and Distributors, pp. 65-103.

Grewal, J. S., and Irfan Habib, eds. 2001. Sikh History from Persian Sources. New Delhi: Tulka Books.

Habermas, Jurgen. 1989. The Structural Transformation of the Public Sphere: An Inquiry into a Category of Bourgeois Society. Translated by Thomas Burger, and Fredrick Lawrence. Cambridge: MIT Press.

Inayatullah, Neem, and David L. Blaney. 2004. International Relations and the Problem of Difference. New York: Routledge.

Jakobsh, Doris R. 2015. Feminizing the Khalsa: Text, narrative and image within the virtual realm. In Encountering Sikh Texts, Practices and Performances: Essays in Honour of Professor Christopher Shackle. 10th Anniversary Issue of Sikh Formations - Religion, Culture, Theory. Oxon: Taylor and Francis Online, vol. 11, pp. 190-209.

Juergensmeyer, Mark. 1993. The New Cold War? Religious Nationalism Confronts the Secular State. Berkeley: University of California Press.

Juergensmeyer, Mark. 2008. Global Rebellion: Religious Challenges to the Secular State from Christian Militias to al Qaeda. Berkeley: University of California Press. 
Kerr, Ian. 1999. Sikhs and State. In Sikh Identity: Continuity and Change. Edited by Pashaura Singh and N. Gerald Barrier. New Delhi: Manohar Publications, pp. 147-74.

Khanna, Ruchika M. 2019. Truce finally reached between warring BJP and Shiromani Akali Dal. The Tribune. April 25. Available online: https://www.tribuneindia.com/news/punjab/truce-finally-reached-betweenwarring-bjp-shiromani-akali-dal/722795.html (accessed on 3 February 2019).

Larson, Gerald James. 1995. India's Agony Over Religion. Albany: State University of New York Press.

Lucia, Amanda. 2019. Lineages, Emerging Exemplars, and Movements post-1947 India. In A Cultural History of Hinduism in the Age of Independence. Edited by Maya Warrier. London, New Delhi, New York and Sydney: Bloomsbury Academic.

Mandair, Arvind-Pal. 2013. Sikhism: A Guide for the Perplexed. London, New Delhi, New York and Sydney: Bloomsbury.

Mandair, Navdeep S. 2014. Colonial Formations of Sikhism. In The Oxford Handbook of Sikh Studies. Edited by Pashaura Singh and Louis E. Fenech. Oxford and New York: Oxford University Press, pp. 70-81.

Mandair, Arvind-Pal. 2015. Sikhs, Sovereignty and Modern Government. In Religion as a Category of Governance and Sovereignty. Edited by Trevor Stack, Naomi R. Goldenberg and Timothy Fitzgerald. Leiden and Boston: Brill, pp. 115-42.

Mann, Gurinder Singh. 1996. The Goindval Pothis: The Earliest Extant Source of the Sikh Canon. Cambridge and London: The Department of Sanskrit and Indian Studies, Harvard University.

Mann, Gurinder Singh. 2004. Sikhism. Upper Saddle River: Prentice Hall Inc.

Mann, Gurinder Singh. 2017. In the Modern World. In Brill's Encyclopedia of Sikhism. Edited by Knut A. Jacobsen, Gurinder Mann Singh, Kristina Myrvold and Eleanor Nesbitt. Leiden and Boston: Brill, vol. I, pp. 113-26.

McLeod, W. Hew. 1989. The Sikhs: History, Religion, and Society. New York: Columbia University Press.

McLeod, Hew. 1997. Sikhism. London: Penguin Books.

McLeod, W. Hew. 2000. Exploring Sikhism: Aspects of Sikh Identity, Culture, and Thought. New Delhi: Oxford University Press.

Nahal, Tarlochan Singh. 2011. Religion and Politics in Sikhism: The Khalsa Perspective. Amritsar: Singh Brothers.

Narang, Amarjit Singh. 2014. The Shiromani Akali Dal. In The Oxford Handbook of Sikh Studies. Edited by Pashaura Singh and Louis E. Fenech. Oxford and New York: Oxford University Press, pp. 339-49.

Oberoi, Harjot. 1988. From Ritual to Counter-Ritual: Re-thinking the Hindu-Sikh Question, 1884-1915. In Sikh History and Religion in the Twentieth Century. Edited by Joseph T. O'Connell and Milton Israel. Toronto: Centre for South Asian Studies, University of Toronto, pp. 136-58.

Oberoi, Harjot. 1994. The Construction of Religious Boundaries: Culture, Identity and Diversity in the Sikh Tradition. Delhi: Oxford University Press.

Ramachandran, T. R. 2002. Sikhism favoured as Separate Religion. The Tribune, April 3.

Scholte, Jan Aart. 2005. Globalization: A Critical Introduction, 2nd ed. Basingstoke: Palgrave.

Shani, Giorgio. 2008. Sikh Nationalism and Identity in a Global Age. London: Routledge.

Shani, Giorgio. 2014. Sikh Nationalism. In The Oxford Handbook of Sikh Studies. Edited by Pashaura Singh and Louis E. Fenech. Oxford and New York: Oxford University Press, pp. 271-81.

Sidhu, Jaspal Singh. 2014. A Study about the Role of Media in Punjab: A Nationalist Perspective of Indian Media. Available online: http://www.countercurrents.org/sidhu290114.html (accessed on 17 April 2019).

Singh, Khushwant. 1999. A History of the Sikhs, Vol. I, 1469-1839. New Delhi: Oxford University Press. First published 1963.

Singh, Kanwarjit. 1989. Political Philosophy of the Sikh Gurus. New Delhi: Atlantic Publishers.

Singh, Gurharpal. 2000. Ethnic Conflict in India: A Case Study of the Punjab. London: Palgrave Macmillan.

Singh, Dalbir. 2006. Sri Guru Arjan Dev Ji. Amritsar: Sikh History Research Board, SGPC.

Singh, Pashaura. 2006. Life and Work of Guru Arjan: History, Memory and Biography in the Sikh Tradition. New Delhi: Oxford University Press.

Singh, Pashaura. 2011. Musical Chaunkis at the Darbar Sahib: History, Aesthetics, and Time. In Sikhism in Global Context. Edited by Pashaura Singh. New Delhi: Oxford University Press, pp. 102-29.

Singh, Pashaura. 2012. Words as Weapons: Theory and Practice of a Righteous War (Dharam Yudh) in Sikh Texts. In Fighting Words: Religion, Violence, and the Interpretation of Sacred Texts. Edited by John Renard. Berkeley and Los Angeles: University of California Press, pp. 200-25. 
Singh, Kashmir. 2014. Shiromani Gurdwara Parbandhak Committee. In The Oxford Handbook of Sikh Studies. Edited by Pashaura Singh and Louis E. Fenech. Oxford and New York: Oxford University Press, pp. 328-38. Singh, Pashaura. 2014. An Overview of Sikh History. In The Oxford Handbook of Sikh Studies. Edited by Pashaura Singh and Louis E. Fenech. Oxford and New York: Oxford University Press, pp. 19-34.

Singh, Pashaura. 2016. Deconstructing the Punjab Crisis of 1984: Deer, hawks, and siqdārs ('officials') as agents of state-sponsored violence. In Sikh Formations: Religion, Culture, Theory. Oxon: Taylor and Francis Online, vol. 12, pp. 173-90.

Singh, Pashaura. 2017. The Sikh Gurus: Works of Art in the Kapany Collection. In Sikh Art from the Kapany Collection. Edited by Paul Michael Taylor and Sonia Dhami. Palo Alto: The Sikh Foundation International, in Association with the Asian Cultural History Program Smithsonian Institution, pp. 50-77.

Singh, I. P. 2019. Panthic politics fluid, focus shifting to agenda. The Times of India, March 11.

Smith, Wilfred Cantwell. 1981. The Crystallization of Religious Communities in Mughal India. In Understanding Islam: Selected Studies. The Hague, Paris and New York: Mouton Publishers.

Strenski, Ivan. 2010. Why Politics Can't Be Freed from Religion. West Sussex: Wiley-Blackwell.

Syan, Hardeep Singh. 2013. Sikh Militancy in the Seventeenth Century: Religious Violence in Mughal and Early Modern India. London and New York: I.B. Tauris.

The Tribune. 2019. Don't Meddle in Gurdwara Affairs, SAD Warns BJP. The Tribune. April 25. Available online: https:/www.tribuneindia.com/news/punjab/don-t-meddle-in-gurdwara-affairs-sad-warns-bjp/ 721208.html (accessed on 31 January 2019).

Truschke, Audrey. 2017. Aurangzeb: The Life and Legacy of India's Controversial King. Stanford: Stanford University Press.

Wallace, Paul. 2011. Sikh Militancy and Non-violence. In Sikhism in Global Context. Edited by Pashaura Singh. New Delhi: Oxford University Press, pp. 85-101.

(C) 2019 by the author. Licensee MDPI, Basel, Switzerland. This article is an open access article distributed under the terms and conditions of the Creative Commons Attribution (CC BY) license (http://creativecommons.org/licenses/by/4.0/). 